\title{
Hapusnya Wewenang Executive Review Pemerintah terhadap Peraturan Daerah: Studi Pasca-adanya Putusan MK Nomor 137/PUU-XIII/2015 dan Nomor 56/PUU XIV/2016
}

\author{
Lusy Liany \\ Fakultas Hukum Yarsi \\ J1 Letjen Suprapto, Jakarta, 10510 \\ E-mail: lusy.liany@yarsi.ac.id
}

\begin{abstract}
The Constitutional Court, on April 4, 2017, through the Decision No.137/PUUXIII/2015 has invalidated the enactment of the rules that enabled a Governor to annul Regency/City Laws. On June 14, 2017, with the Decision No.56/PUUXIV/2016, the Court also invalidated the authority of Ministry of Internal Affair to void Provincial Laws. These decisions brought about a question on whether the government still has the authority to revise those regional laws or it can only be taken through the material review to the judiciary. Based on the background, the authors formulated two problems. Firstly, what is the mechanism of government control of the Regional Regulation after the Constitutional Court Decision Number 137 / PUU-XIII / 2015 and the Court's Decision Number 56/PUU$\mathrm{XIV} / 2016$ ? Secondly, what are the obstacles to judicial review of regional regulations in the Supreme Court? The research method applied in this paper is a normative method in which qualitative data are gathered and the statute and conceptual approaches are employed. First result, the government, both the Minister of Internal Affairs and the Governor, can oversee the regional lawmaking process through the executive preview mechanism and the annulation of both Province and Regency/City Laws is in the domain of the Supreme Court's authority. Second, the judicial review process in the Supreme Court has not fully met the legal principles of judicial review process, as it is not open to public, there is no deadline to finish the trial, and the Supreme Court's decision is not supported by sufficient details of judges' legal opinion.
\end{abstract}

Keywords: Government, Regional Laws, Supreme Court

\begin{abstract}
Abstrak
Mahkamah Konstitusi, pada 4 April 2017, melalui Putusan Nomor 137/PUUXIII/2015 telah membatalkan berlakunya aturan terkait kewenangan Gubernur dalam membatalkan Perda Kabupaten/Kota. Pada 14 Juni 2017, melalui Putusan Nomor 56/PUU-XIV/2016, MK juga membatalkan berlakunya kewenangan Kemendagri dalam membatalkan Perda Provinsi. Dengan dua putusan MK diatas yang menyisakan pertanyaan apakah pemerintah masih mempunyai kewenangan untuk merevisi Perda atau hanya dapat ditempuh melalui pengujian materil kepada lembaga peradilan. Maka dari pada itu, penulis merumuskan dua permasalahan yaitu: Bagaimanakah mekanisme kontrol pemerintah terhadap Perda pasca Putusan MK Nomor 137/PUU-XIII/2015 dan Putusan MK Nomor
\end{abstract}


56/PUU-XIV/2016 dan bagaimanakah kendala judicial review Peraturan Daerah di Mahkamah Agung. Metode penulisan yang digunakan adalah metode normatif, data kualitatif dengan pendekatan undang-undang (statute approach) dan pendekatan konseptual (conseptual approach). Adapun hasil pembahasan pertama, pemerintah dalam hal ini Mendagri ataupun Gubernur dapat merevisi pembentukan perda melalui mekanisme executive preview dan pembatalan Perda baik Provinsi dan Kabupaten/Kota satu-satunya menjadi ranah kewenangan Mahkamah Agung. Kedua, proses judicial review Perda di Mahkamah Agung belum sepenuhnya mengakomodir asas-asas hukum acara pengujian peraturan perundang-undangan, dimana perkara disidangkan secara tertutup dan sepihak, tidak menentukan batas waktu yang jelas mengenai kapan suatu permohonan disidangkan dan putusan MA tidak disertai pendapat hukum hakim secara mendetail.

Kata Kunci: Perda, Pemerintah, Mahkamah Agung

\section{Pendahuluan}

Wewenang untuk menguji peraturan perundang-undangan di Indonesia pasca-amandemen Undang-Undang Dasar 1945 (UUD 1945) diberikan kepada dua lembaga pelaksana kekuasaan kehakiman, yaitu Mahkamah Agung (MA) dan Mahkamah Konstitusi (MK). ${ }^{1}$ Wewenang kekuasaan kehakiman untuk melakukan pengujian peraturan perundang-undangan dengan adanya perubahan tersebut telah diperkuat dan dipertegas legitimasi yuridisnya, mengingat wewenang demikian hanya diatur melalui undang-undang sebelumnya, yaitu Undang-Undang Nomor 14 Tahun 1970 tentang Kekuasaan Kehakiman. Namun, kemajuan dalam pengaturan mekanisme pengujian peraturan perundang-undangan ini bukan berarti tanpa permasalahan.

Presiden, sebelum ini, mengumumkan pembatalan Peraturan Daerah (Perda) pada 13 Juni 2016 di Istana Merdeka. Beberapa hari kemudian, Kementerian Dalam Negeri (Kemendagri) juga mengunggah daftar Perda/Peraturan Kepala Daerah (Perkada) dan Peraturan Menteri Dalam Negeri (Permendagri) yang

${ }^{1}$ MA untuk menguji peraturan perundang-undangan di bawah undang-undang terhadap undang-undang. Sedangkan MK untuk menguji undang-undang terhadap UUD 1945. Pasal 24A ayat (1) dan Pasal 24C ayat (1) Undang-Undang Dasar 1945. 
dibatalkan/direvisi. Secara keseluruhan, sebanyak 3.143 peraturan telah dibatalkan/direvisi, dengan rincian sebagai berikut: 1.765 Perda/Perkada Kabupaten/Kota dicabut atau direvisi oleh Kemendagri dan 1.267 Perda/Perkada Kabupaten/Kota direvisi oleh Gubernur.

Sebanyak 47 Kepala Daerah yang tergabung dalam Asosiasi Pemerintah Kabupaten Seluruh Indonesia (Apkasi), berdasarkan realitas di atas, kemudian mengajukan pembatalan terkait wewenang Gubernur dan Menteri Dalam Negeri (Mendagri) dalam pembatalan Perda Provinsi dan Perda Kabupaten/Kota, sebagaimana diatur melalui Pasal 251 Undang-Undang Nomor 23 Tahun 2014 tentang Pemerintah Daerah (UU Pemda). Dalam perkembangannya, pada 4 April 2017, melalui Putusan Nomor 137/PUUXIII/2015, aturan terkait wewenang Gubernur untuk membatalkan Perda Kabupaten/Kota dibatalkan oleh MK. Selanjutnya, pada 14 Juni 2017, melalui Putusan Nomor 56/PUU-XIV/2016, MK juga membatalkan aturan tentang wewenang Mendagri untuk membatalkan Perda Provinsi.

Pemohon dalam perkara yang diputus melalui putusan MK tersebut mendalilkan bahwa pasal yang diujikan telah, atau setidaknya berpotensi, untuk menghambat hak-hak konstitusional para pemohon dalam melaksanakan otonomi daerah dan pengembangan daerah dengan keragaman dan kekhasannya masingmasing, sebagaimana diamanatkan oleh Pasal 18 ayat (2) dan ayat (5), serta Pasal 18A ayat (1) UUD 1945.2 Pemohon juga mendalilkan bahwa Pemerintah Daerah Kabupaten/Kota sangat sulit untuk melakukan penambahan atau perubahan kewenangan terkait kebutuhan Pemerintah Daerah dalam urusan pemerintahan

2 Lulu Anjarsari "Pembatalan Perda Kabupaten/Kota (Menjadi) Kewenangan MA" (Jakarta, Jurnal Konstitusi No. 123, Mei 2017), hlm. 13. 
konkruen yang dianggap merupakan bagian penting dari otonomi daerah, sebagaimana yang diatur dalam UU Pemda. ${ }^{3}$

Pemohon, selanjutnya, ingin mengembalikan hak konstitusional bagi pemerintahan daerah untuk mengatur dan mengurus sendiri urusan pemerintahan menurut asas otonomi. ${ }^{4}$ Hal ini juga merupakan perwujudan dari desentralisasi pemerintahan yang demokratis. Pasalnya, pemberian otonomi yang seluas-luasnya kepada daerah diarahkan untuk memercepat terwujudnya kesejahteraaan masyarakat melalui peningkatan pelayanan, pemberdayaan, dan peran serta masyarakat. ${ }^{5}$

Perda, sebagaimana diketahui, merupakan peraturan perundangan-undangan yang dibentuk oleh Dewan Perwakilan Rakyat Daerah (DPRD) dengan persetujuan bersama Kepala Daerah (Gubernur atau Bupati/Walikota). ${ }^{6}$ Perda secara umum merupakan ketentuan yang bersifat mengatur (regeling) untuk melaksanakan peraturan-peraturan lain yang lebih tinggi derajatnya dan dibentuk oleh Kepala Daerah (eksekutif) dan DPRD (legislatif), yang keduanya dipilih

${ }^{3}$ Ibid.

${ }^{4}$ Mahkamah Konstitusi, Putusan Nomor 137/PUU-XIII/2015. Dalam alasan permohonan pemohon disebutkan bahwa kembali mengingatkan salah satu tonggak sejarah penting perjalanan bangsa dan Negara Republik Indonesia adalah reformasi yang terjadi pada tahun 1998. Teriakan reformasi yang digaungkan oleh para mahasiswa dan segenap komponen bangsa telah melahirkan sebuah orde yang menggantikan rezim otoritarian serta melahirkan banyak perubahan fundamental politik dan ketatanegaraan seiring dengan perubahan Konstitusi sebagai wujud kongkrit dari tuntutan tersebut. Salah satu yang menjadi buah reformasi adalah Pasal 18 ayat (2) UUD 1945 memberikan dasar kewenangan konstitusional bagi pemerintahan daerah untuk mengatur dan mengurus sendiri urusan pemerintahan menurut asas otonomi.

5 Mahkamah Konstitusi, Putusan Nomor 137/PUU-XIII/2015. Menimbang, bahwa dasar filosofis pemberian otonomi seluas-luasnya kepada daerah dalam mengurus sendiri urusan pemerintahan sebagaimana diatur Pasal 18 ayat (2) dan ayat (5) UUD 1945 adalah dalam rangka demokrasi politik dalam hubungan antar pemerintahan daerah dan pemerintah pusat.

6 Bagir Manan, "Dasar-dasar Perundang-undangan Indonesia",( Jakarta: Indonesia Hill,1999), hlm. 63. Perda terdiri dari Perda Provinsi dan Perda Kabupaten/Kota. Perda Provinsi adalah peraturan perundang-undangan yang dibentuk oleh DPRD Provinsi dengan persetujuan bersama Gubernur. Sedangkan Perda Kabupaten/Kota adalah peraturan perundangan-undangan yang dibentuk oleh DPRD Kabupaten/Kota dengan persetujuan bersama Bupati/Walikota. Lihat, Pasal 1 Angka 7 dan 8 UU No. 12 Tahun 2011 tentang Pembentukan Peraturan PerundangUndangan. 
secara langsung melalui pemilihan umum. ${ }^{7}$ Dengan demikian, secara formil, pembentukan Perda merupakan manifestasi dari kedaulatan rakyat. Sedangkan secara materil, Perda merupakan formulasi hukum atas kebutuhan dan kekhasan lokal masing-masing daerah. ${ }^{8}$

MK demi kepastian hukum telah memutus pengujian Perda menjadi ranah kewenangan dari MA. Tetapi, pembatalan Perda yang hanya melalui MA berpotensi berjalan secara tidak efektif. Hal ini dikarenakan kedepannya setiap orang yang ingin menguji Perda mau tidak mau harus berkonflik secara terbuka dengan Pemda di ranah pengadilan. Hal demikian tentunya sangat tidak menguntungkan, terutama, sebagai contoh, bagi pelaku usaha di daerah. Pelaku usaha, sebagaimana diketahui, cenderung menghindari permasalahan yang dapat menjadi perhatian publik karena pentingnya menjaga nama baik. Selain itu, pelaku usaha di sisi lain juga membutuhkan hubungan baik dengan Pemda, terutama pada aspek izin dan perpajakan. Jika harus berkonflik dengan Pemda secara terbuka, maka gugatan melalui MA bukanlah pilihan yang tepat, khususnya bagi pelaku usaha. Hal ini jauh lebih konkret dan menghindari konflik terbuka dengan Pemda.

Menempatkan MA sebagai satu-satunya lembaga yang berwenang menguji Perda berpotensi menghambat pengawasan terhadap Perda-perda ex-post (setelah diundangkan). Sifat MA yang pasif (menunggu permohonan) dalam melihat Perda-perda yang bermasalah juga akan menghambat pengawasan Perda secara menyeluruh pada tahap ex-post. Maka dari itu, mekanisme pengawasan pemerintah terhadap Perda Kab/Kota maupun Provinsi menjadi penting untuk hlm. 136.

${ }^{7}$ Bagir Manan, Menyongsong Fajar Otonomi Daerah, (Yogyakarta: PSH FH UII, 2002), ${ }^{8}$ Ibid. 
dikaji kembali, mengingat telah hilangnya wewenang pemerintah, baik Kemendagri dan Gubernur, dalam pembatalan Perda Provinsi dan/atau Kabupaten/Kota secara menyeluruh.

\section{Rumusan Masalah}

Berdasarkan latar belakang permasalahan yang penulis ungkapkan, terdapat dua rumusan masalah. Pertama, bagaimana mekanisme kontrol Pemerintah dan Lembaga Peradilan terhadap peraturan daerah pasca-adanya Putusan MK Nomor 137/PUU-XIII/2015 dan Nomor 56/PUU-XIV/2016? Kedua, bagaimana kendala judicial review Peraturan Daerah di Mahkamah Agung?

\section{Tujuan Penelitian}

Tujuan dari penelitian ini adalah sebagai berikut. Pertama, menjelaskan mekanisme kontrol Pemerintah dan Lembaga Peradilan terhadap peraturan daerah pasca-adanya Putusan MK Nomor 137/PUU-XIII/2015 dan Nomor 56/PUUXIV/2016. Kedua, menjelaskan bagaimana kendala pada proses judicial review Peraturan Daerah di Mahkamah Agung.

\section{Metode Penelitian}

Penelitian ini merupakan penelitian hukum normatif yang menekankan pada materi hukum tentang hapusnya wewenang pembatalan Perda Provinsi dan Kabupaten/Kota pasca-adanya Putusan MK Nomor 137/PUU-XIII/2015 dan Nomor 56/PUU XIV/2016. Penelitian ini bersifat deskriptif dan sumber data yang digunakan adalah data sekunder, yang terdiri dari bahan hukum primer, berupa peraturan perundang-undangan yang terkait dengan penelitian, antara lain yaitu Undang-Undang Dasar Negara Republik Tahun 1945 (UUD NRI 1945), UndangUndang Nomor 3 Tahun 2009 tentang Mahkamah Agung, Undang-Undang 
Nomor 12 Tahun 2011 tentang Pembentukan Peraturan Perundang-undangan, Undang-Undang Nomor 23 Tahun 2014 tentang Pemerintah Daerah, Peraturan Mahkmah Agung Nomor 1 Tahun 2011 tentang Hak Uji Materil, Putusan MK Nomor 137/PUU-XIII/2015 dan Putusan MK Nomor 56/PUU-XIV/2016, serta data sekunder berupa buku-buku teks, jurnal-jurnal hukum, makalah, hasil penelitian yang terdahulu, serta risalah sidang pembentukan dan perubahan UUD 1945. Analisis data dilakukan secara kualitatif, yaitu dengan menafsirkan peristiwa hukum yang terjadi dengan cara mengumpulkan semua bahan yang diperlukan yang bukan merupakan angka-angka dan menghubungkannya dengan permasalahan yang ada. Pendekatan utama dalam penelitian ini adalah perundangundangan (statute) dan konseptual (conceptual).

\section{Hasil Penelitian dan Pembahasan}

Mekanisme Kontrol Pemerintah dan Lembaga Peradilan terhadap Peraturan Daerah pasca-Adanya Putusan MK Nomor 137/PUU-XIII/2015 dan Nomor 56/PUU-XIV/2016

Hak menguji merupakan hak untuk memeriksa, menilai, dan memutus tingkat keselarasan suatu peraturan perundang-undangan yang lebih rendah terhadap peraturan perundang-undangan yang derajatnya lebih tinggi. ${ }^{9}$ Terdapat dua jenis hak menguji. Pertama, hak menguji formal (formele toetsingsrecht), yaitu wewenang untuk menilai apakah suatu produk legislatif misalnya, dibentuk melalui cara-cara (procedures) yang telah ditentukan/diatur dalam peraturan perundang-undangan yang berlaku. Pengujian formal juga biasanya terkait dengan soal-soal prosedural yang berkenaan dengan legalitas kompetensi institusi yang

9 Tentu saja, peraturan perundang-undangan tersebut dibuat oleh lembaga negara yang diberi wewenang pengujian oleh undang-undang dasar dan/atau undang-undang. 
membuatnya. ${ }^{10}$ Menurut Harun Alrasid, hak menguji formal berkaitan dengan prosedur pembuatan undang-undang.

Kedua, hak menguji material (materiele toetsingsrecht), yaitu suatu wewenang untuk menyelidiki dan menilai apakah suatu peraturan perundangundangan isinya sesuai atau bertentangan dengan peraturan yang secara hirarkis lebih tinggi derajatnya, serta apakah suatu kekuasaan tertentu (verordenende macht) berwenang mengeluarkan suatu peraturan tertentu atau tidak. ${ }^{11}$

Secara kelembagaan, terdapat tiga jenis lembaga yang berwenang melakukan pengujian. Pertama, lembaga eksekutif melalui eksekutif review, yaitu wewenang lembaga eksekutif untuk menguji suatu perundang-undangan. Wewenang ini membuat lembaga eksekutif dapat membatalkan suatu perundangundangan apabila dipandang bertentangan dengan peraturan yang lebih tinggi hirarkinya atau kepentingan umum. ${ }^{12}$ Kedua, lembaga yurdikatif melalui judicial review, yaitu pengujian yang dilakukan melalui mekanisme peradilan atas kebenaran suatu norma tertentu terhadap norma yang lebih tinggi. Ketiga, lembaga legislatif melalui legislatif review, yaitu pengujian peraturan perundangundangan yang dilakukan oleh lembaga legislatif. Lembaga legislatif sebagai pembuat undang-undang memiliki hak untuk melakukan peninjauan atau perubahan peraturan perundang-undangan. ${ }^{13}$

Di Indonesia, praktik executive review pernah dilakukan berdasarkan Undang-Undang Nomor 23 Tahun 2014 tentang Pemerintah Daerah (UU Pemda). Berdasarkan UU Pemda, Pemerintah Pusat, dalam hal ini Kemendagri dan

\footnotetext{
${ }^{10}$ Maria Farida Indrati, Ilmu Perundang-undangan, Kanisius, Jakarta, 2016, hlm. 53

11 Jimly Asshiddiqie, Loc.Cit.

12 Jimly Asshiddiqie, Perihal Undang-Undang, RajaGrafindo Persada, Jakarta, 2014, hlm.

${ }^{13}$ Fatmawati, Hak Menguji (Toetsingsrecht), Rajawali Pers, Jakarta, 2006, hlm. 36
} 
Gubernur, dapat membatalkan Perda jika Pemerintah Pusat berpendapat bahwa

Perda yang dibuat oleh Pemerintah Daerah bertentangan dengan peraturan perundang-undang yang lebih tinggi dan/atau bertentangan dengan kepentingan umum. ${ }^{14}$ Tetapi, wewenang ini dihapus karena adanya Putusan MK Nomor 137/PUU-XIII/2015 dan Nomor 56/PUU-XIV/2016. Walaupun begitu, Pemerintah Pusat dalam konteks Negara Kesatuan Republik Indonesia yang berdasarkan pada UUD NRI 1945 pada dasarnya masih berwenang untuk mengontrol unit-unit pemerintahan daerah provinsi ataupun pemerintahan daerah kabupaten $/$ kota. $^{15}$

14 Pasal 251 UU Nomor 23 Tahun 2014 tentang Pemerintah Daerah: (1) Perda Provinsi dan peraturan gubernur yang bertentangan dengan ketentuan peraturan perundang-undangan yang lebih tinggi, kepentingan umum, dan/atau kesusilaan dibatalkan oleh Menteri; (2) Perda Kabupaten/Kota dan peraturan bupati/wali kota yang bertentangan dengan ketentuan peraturan perundangundangan yang lebih tinggi, kepentingan umum, dan/atau kesusilaan dibatalkan oleh gubernur sebagai wakil Pemerintah Pusat; (3) Dalam hal gubernur sebagai wakil Pemerintah Pusat tidak membatalkan Perda Kabupaten/Kota dan/atau peraturan bupati/wali kota yang bertentangan dengan ketentuan peraturan perundang-undangan yang lebih tinggi, kepentingan umum, dan/atau kesusilaan sebagaimana dimaksud pada ayat (2), Menteri membatalkan Perda Kabupaten/Kota dan/atau peraturan bupati/wali kota; (4) Pembatalan Perda Provinsi dan peraturan gubernur sebagaimana dimaksud pada ayat (1) ditetapkan dengan keputusan Menteri dan pembatalan Perda Kabupaten/Kota dan peraturan bupati/wali kota sebagaimana dimaksud pada ayat (2) ditetapkan dengan keputusan gubernur sebagai wakil Pemerintah Pusat; (5) Paling lama 7 (tujuh) Hari setelah keputusan pembatalan sebagaimana dimaksud pada ayat (4), kepala daerah harus menghentikan pelaksanaan Perda dan selanjutnya DPRD bersama kepala daerah mencabut Perda dimaksud; (6) Paling lama 7 (tujuh) Hari setelah keputusan pembatalan sebagaimana dimaksud pada ayat (4), kepala daerah harus menghentikan pelaksanaan Perkada dan selanjutnya kepala daerah mencabut Perkada dimaksud; (7) Dalam hal penyelenggara Pemerintahan Daerah provinsi tidak dapat menerima keputusan pembatalan Perda Provinsi dan gubernur tidak dapat menerima keputusan pembatalan peraturan gubernur sebagaimana dimaksud pada ayat (4) dengan alasan yang dapat dibenarkan oleh ketentuan peraturan perundang-undangan, gubernur dapat mengajukan keberatan kepada Presiden paling lambat 14 (empat belas) hari sejak keputusan pembatalan Perda atau peraturan gubernur diterima; (8) Dalam hal penyelenggara Pemerintahan Daerah kabupaten/kota tidak dapat menerima keputusan pembatalan Perda Kabupaten/Kota dan bupati/wali kota tidak dapat menerima keputusan pembatalan peraturan bupati/wali kota sebagaimana dimaksud pada ayat (4) dengan alasan yang dapat dibenarkan oleh ketentuan peraturan perundang-undangan, bupati/wali kota dapat mengajukan keberatan kepada Menteri paling lambat 14 (empat belas) Hari sejak keputusan pembatalan Perda Kabupaten/Kota atau peraturan bupati/wali kota diterima.

15 Sejak mula dibuatnya konstitusi pertama, UUD 1945, telah diadopsi model negara kesatuan ('eenheidsstaat') yang disusun berdasarkan desentralisasi. UUD 1945 yang disahkan Panitia Persiapan Kemerdekaan Indonesia (PPKI) di kala tanggal 18 Agustus 1945, memuat dalam Pasal 18 UUD 1945 (redaksi lama), di bawah Bab VI, bertajuk Pemerintahan Daerah, bahwasanya "Pembagian daerah Indonesia atas daerah besar dan kecil, dengan bentuk susunan pemerintahannya ditetapkan dengan undangundang, dengan memandang dan mengingati dasar permusyawaratan dalam sistem pemerintahan negara, dan hak asal-usul dalam daerah-daerah yang 
MK, jika dilihat dari pertimbangannya, menjelaskan bahwa dalam perspektif negara kesatuan (unitary state, eenheiddsstaat) adalah logis jika pemerintahan pusat berwenang untuk mengontrol unit-unit pemerintahan daerah provinsi ataupun pemerintahan daerah kabupaten $/$ kota. ${ }^{16}$ Salah satunya diwujudkan dengan memiliki wewenang executive preview, sebuah mekanisme pengawasan preventif. Model pengawasan preventif ini secara umum dibedakan menjadi dua macam. ${ }^{17}$ Pertama, sebelum rancangan Perda dilaksanakan oleh kepala daerah, rancangan tersebut terlebih dahulu dievaluasi oleh Menteri Dalam Negeri. Kedua, pengesahan dari Menteri Dalam Negeri atau Gubernur terhadap rancangan peraturan kepala daerah tentang APBD.

Fungsi pengawasan pada dasarnya dapat dilakukan setiap saat, mulai sejak proses pelaksanaan kegiatan pemerintahan hingga setelah berakhirnya masa pemerintahan. Tujuannya adalah untuk mengetahui tingkat kinerja dan pencapaian pemerintah. ${ }^{18}$ Fungsi tersebut dilakukan terhadap perencanaan dan pelaksanaan. Pengawasan dilakukan untuk melaksanakan perbaikan bila terdapat kekeliruan atau penyimpangan sebelum menjadi lebih buruk sehingga sulit untuk diperbaiki. Dalam hal pembatalan Perda, peran Pemerintah Pusat melalui Kemendagri untuk

sifatnya istimewa". H.M. Lihat, Laica Marzuki, Hakikat Desentralisasi dalam Sistem Ketatanegaraan dalam Jurnal Konstitusi Vol. 4, No. 1, Maret 2017, h. 7.

${ }^{16}$ Sejak mula dibuatnya konstitusi pertama, UUD 1945, telah diadopted model negara kesatuan ('eenheidsstaat') yang disusun berdasarkan desentralisasi. UUD 1945 yang disahkan Panitia Persiapan Kemerdekaan Indonesia (PPKI) di kala tanggal 18 Agustus 1945, memuat dalam Pasal 18 UUD 1945 (redaksi lama), di bawah Bab VI, bertajuk Pemerintahan Daerah, bahwasanya "Pembagian daerah Indonesia atas daerah besar dan kecil, dengan bentuk susunan pemerintahannya ditetapkan dengan undangundang, dengan memandang dan mengingati dasar permusyawaratan dalam sistem pemerintahan negara, dan hak asal-usul dalam daerah-daerah yang sifatnya istimewa". H.M. Lihat, Laica Marzuki, Hakikat Desentralisasi dalam Sistem Ketatanegaraan Jurnal Konstitusi, (Jakarta: Jurnal Konstitusi Vol. 4, No. 1, Maret 2017), hlm. 7.

${ }^{17}$ Yuniar Kurniawati, "Polemik Pengujian Peraturan Daerah (UU No.48 Tahun 2009 tentang Kekuasaan Kehakiman Versus UU No.23 Tahun 2014 tentang Pemerintahan Daerah", (Jakarta: Jurnal Litigasi Kementerian Hukum dan HAM Vol. 13 No. 4, Desember 2016), hlm. 344.

${ }^{18} \mathrm{http} / / / \mathrm{www}$. negarahukum.com/hukum/teori-pengawasan.html diakses 5 Februari 2018 
mengawasi proses pembentukan Perda Provinsi dan peran Pemerintah Provinsi melalui Gubernur untuk mengawasi proses pembentukan Perda Kabupaten/Kota yang dilakukan secara preventif terhadap rancangan Perda ini disebut dengan executive preview.

Wewenang executive preview diberikan dalam rangka mengendalikan penyelenggaraan Pemerintahan Daerah, baik pada tingkat Provinsi maupun Kabupaten/kota, khususnya di bidang pengaturan. Secara umum, pemerintah atasan dapat mengontrol proses pembuatan Perda dengan mengunakan mekanisme executive preview ini, bukan mekanisme review atas Perda yang sudah berlaku dan mengikat untuk umum. ${ }^{19}$ Oleh karena itu, preview terhadap peraturan daerah, sebagai produk legislatif di daerah, dapat dilakukan oleh pemerintahan atasan apabila statusnya masih sebagai rancangan peraturan daerah yang belum mengikat untuk umum. Jika peraturan daerah itu sudah mengikat untuk umum, maka untuk pembatalan perda tersebut dapat ditempuh melalui lembaga peradilan yaitu Mahkamah Agung. ${ }^{20}$

Mekanisme executive preview yang dijalankan oleh Menteri atau Gubernur selaku wakil dari Pemerintah Pusat dilaksanakan pada saat memberikan nomor registrasi atas rancangan Perda Provinsi atau Kabupaten/Kota selama paling lambat tujuh hari sejak rancangan Perda diterima oleh Menteri atau Gubernur. Terhadap rancangan Perda Provinsi yang belum diberikan nomor pendaftaran oleh Menteri atau rancangan Perda Kabupaten/Kota oleh Gubernur, rancangan Perda tersebut belumlah dapat diundangkan dalam lembaran daerah. ${ }^{21}$ Selain itu, UU

\footnotetext{
${ }^{19}$ Jimly Asshiddiqie, Perihal Undang-Undang...Op.Cit., hlm. 75.

${ }^{20}$ Ibid.

${ }^{21}$ Pasal 242 ayat (5) dan Pasal 243 ayat (1) UU No. 23 Tahun 2014 tentang Pemerintahan Daerah.
} 
Pemda juga mengatur bahwa rancangan Perda yang berkaitan dengan APBD, pajak, retribusi, dan tata ruang harus diajukan kepada Pemerintah untuk dievaluasi. ${ }^{22}$

Proses registrasi dan evaluasi tersebut dapat dijadikan peluang oleh Pemerintah untuk mengawasi kualitas suatu Perda. Pemerintah melalui Kemendagri perlu melakukan penataan ulang untuk pelaksanaan pengawasan preventif ini. Kekuatan pengawasannya memang tidak seperti yang sebelumnya, yaitu sampai pada kewenangan untuk membatalkan. ${ }^{23}$ Oleh karena itu, terhadap peraturan daerah, sebagai produk legislatif di daerah, hanya dilakukan preview oleh pemerintahan atasan saat statusnya masih sebagai rancangan peraturan daerah yang belum mengikat untuk umum. Jika peraturan daerah itu sudah mengikat untuk umum, maka yang menguji adalah lembaga peradilan sebagai pihak ketiga yang sama sekali tidak terlibat dalam proses pembentukan peraturan daerah yang bersangkutan. ${ }^{24}$ Pada akhirnya, Pemerintah harus lebih serius dan lebih ketat dalam melakukan supervisi atau mengawal pembuatan Perda ini untuk menyaring rancangan Perda sebelum menjadi Perda. Hal itu dengan demikian diharapkan dapat mencegah atau setidaknya mengurangi kasus-kasus Perda yang bertentangan dengan peraturan perundang-undangan yang lebih tinggi dan/atau bertentangan dengan kepentingan umum.

Satu-satunya lembaga pengadilan yang dapat membatalkan Perda dengan adanya Putusan MK Nomor 137/PUU-XIII/2015 dan Nomor 56/PUU-XIV/2016 adalah MA. Hal ini juga ditegaskan dan selaras dengan Pasal 24A ayat (1) UUD

22 M. Nur Sholikin, "Penghapusan Kewenangan Pemerintah Untuk Membatalkan Perda;Momentum Mengefektifkan Pengawasan Preventif dan Pelaksanaan Hak Uji Materil MA", dalam Jurnal RechtsVinding, 2017, hlm. 4.

${ }_{23}^{3}$ Jimly Asshiddiqie, Perihal Undang-Undang...Loc.Cit.

${ }^{24}$ Ibid. 
NRI 1945 yang menyebutkan bahwa salah satu wewenang MA yaitu menguji peraturan perundang-undangan di bawah undang-undang terhadap undangundang. Selain itu, diatur lebih lanjut dalam Pasal 20 ayat (2) huruf b UndangUndang Nomor 48 Tahun 2009 tentang Kekuasaan Kehakiman jo. Pasal 31 ayat (1) Undang-Undang Nomor 5 Tahun 2004 tentang Mahkamah Agung, bahwa MA mempunyai wewenang untuk menguji peraturan perundang-undangan di bawah undang-undang terhadap undang-undang. Kewangan ini dimaksudkan untuk memberikan perlindungan hukum bagi rakyat atas regulasi yang dibuat oleh Pemerintah. $^{25}$

Secara historis, gagasan tentang pentingnya wewenang menguji peraturan perundang-undangan di MA pernah diajukan oleh Prof. H. Muhammad Yamin dalam pidatonya pada waktu penyusunan Rancangan UUD 1945 dalam rapat besar Badan Penyelidik Usaha-usaha Persiapan Kemerdekaan (BPUPK), 15 Juli 1945. ${ }^{26}$ Dipertegas dengan lahirnya UU No. 12 Tahun 2011 tentang Pembentukan Peraturan Perundang-undangan, Perda telah tegas masuk ke dalam hirarki peraturan perundang-undangan. ${ }^{27}$ Dengan demikian, kewenangan untuk menguji

${ }^{25}$ Abdul Ghoffar, "Kuasa Membatalkan Undang-Undang”, dalam Jurnal Konstitusi No. 122, April 2017, hlm. 67.

${ }^{26}$ Pada saat itu, Prof. H. Muhammad Yamin membicarakan kekuasaan yang enam, yaitu kekuasaan Presiden dan Wakil Presiden, kekuasaan Kementerian, kekuasaan Mahkamah Agung, kekuasaan Dewan Pertimbangan Agung, kekuasaan Dewan Perwakilan Rakyat, dan kekuasaan Majelis Permusyawaratan Rakyat, antara lain dikatakannya sebagai berikut: Mahkamah Agung melalukan kekuasaan kehakiman dan membanding undang-undang supaya sesuai dengan hukum adat, hukum islam (syariah), dan dengan Undang-Undang Dasar dan melaksanakan aturan pembatalan undang-undang, pendapat Balai Agung disampaikan kepada Presiden yang mengabarkan berita kepada Dewan Perwakilan. Kemudian pada bagian lain dalam rapat yang sama, Prof. H. Muhammad Yamin mengatakan sebagai berikut: Balai Agung (maksudnya Mahkamah Agung) janganlah saja melaksanakan bagian kehakiman, tetapi juga_hendaklah menjadi badan yang membanding, apakah undang-undang yang dibuat oleh Dewan Perwakilan Rakyat tidak melanggar Undang-Undang Dasar Republik atau bertentangan dengan hukum adat yang berlaku. Dikutip dari Boli Sabon Max sebagai saksi ahli pemohon dalam Putusan MK Nomor 137/PUU-XIII/2015.

27 Aziz Syamsuddin, Proses dan Teknik Penyusunan Undang-Undang, (Jakarta: Sinar Grafika, 2013), hlm. 46. 
apakah Perda bertentangan dengan peraturan perundang-undangan yang lebih tinggi ada pada MA.

Pembatalan Perda Kabupaten/Kota melalui keputusan gubernur, jika dilihat dalam hirarkhi UU No. 12 Tahun 2011, juga tidak sesuai dengan rezim peraturan perundang-undangan sehingga tidak dapat dijadikan produk hukum untuk membatalkan Perda Kabupaten/Kota. Berdasarkan Pasal 7 ayat (1) dan Pasal 8 UU No. 12 Tahun 2011, tidak terdapat keputusan gubernur sebagai salah satu jenis dan hierarki peraturan perundang-undangan. ${ }^{28}$

Secara filosofis, pada hakekatnya, jenis dan hirarki peraturan perundangundangan Indonesia berada dalam satu kesatuan sistem nilai yang integral sesuai dengan teori norma hukum, teori Stufenbau De Recht atau The Hirarchi of Law Theory dari Hans Kelsen. Artinya, antara satu jenis dan hirarki peraturan perundang-undangan yang satu dengan yang lainnya terjalin satu kesatuan nilai

\footnotetext{
${ }^{28}$ Pasal 7 ayat (1) UU No. 12 Tahun 2011 tentang Pembentukan Peraturan PerundangUndangan. Jenis dan hierarki Peraturan Perundang-undangan terdiri atas:

(1) Undang-Undang Dasar Negara Republik Indonesia Tahun 1945;

(2) Ketetapan Majelis Permusyawaratan Rakyat;

(3) Undang-Undang/Peraturan Pemerintah Pengganti Undang-Undang;

(4) Peraturan Pemerintah;

(5) Peraturan Presiden;

(6) Peraturan Daerah Provinsi; dan

(7) Peraturan Daerah Kabupaten/Kota.

Pasal 8 ayat (1) UU No. 12 Tahun 2011 tentang Pembentukan Peraturan Perundang-Undangan menyebutkan bahwa:

"Jenis Peraturan Perundang-undangan selain sebagaimana dimaksud dalam Pasal 7 ayat (1) mencakup peraturan yang ditetapkan oleh Majelis Permusyawaratan Rakyat, Dewan Perwakilan Rakyat, Dewan Perwakilan Daerah, Mahkamah Agung, Mahkamah Konstitusi, Badan Pemeriksa Keuangan, Komisi Yudisial, Bank Indonesia, Menteri, badan, lembaga, atau komisi yang setingkat yang dibentuk dengan UndangUndang atau Pemerintah atas perintah Undang-Undang, Dewan Perwakilan Rakyat Daerah Provinsi, Gubernur, Dewan Perwakilan Rakyat Daerah Kabupaten/Kota, Bupati/Walikota, Kepala Desa atau yang setingkat”.
} 
yang saling mendasari, sampai pada suatu nilai tertinggi yang disebut dengan grudnorm atau staats fundamental norm..$^{29}$

Lembaga peradilan, selanjutnya, yang diberikan wewenang untuk melakukan judicial review Perda cukup satu lembaga peradilan, yaitu MA, agar dapat lebih menjamin satu kesatuan sistem nilai yang integral sesuai dengan teori Stufenbau De Recht atau The Hirarchi of Law Theory dari Hans kelsen. ${ }^{30}$ Dengan dijadikannya MA sebagai satu-satunya lembaga judicial review Perda, hal ini sesuai dengan sistem yang dianut dan dikembangkan menurut UUD 1945, yakni centralized model of judicial review bukan decentralized model seperti yang ditentukan dalam Pasal 24A ayat (1) dan Pasal 24C ayat (1) UUD NRI 1945. ${ }^{31}$

Sistem hukum Indonesia lebih bercorak civil law (sistem hukum eropa) dibandingkan dengan common law, meskipun pasca reformasi dan amandemen UUD NRI 1945 telah terjadi pengadopsian beberapa aspek sistem hukum rule of law. ${ }^{32}$ Dalam negara yang menganut sistem hukum civil law, judicial review

29 Jimly Asshidiqie dan M. Ali Safa'at, Teori Hans Kelsen tentang Hukum, (Jakarta: Konstitusi Press dan PT. Syaamsil Cipta Media, 2006), hlm. 176-179.

${ }^{30}$ Hans Kelsen, General Theory of Law and State, Transleted by Anders Wedberg, (New York: Russell and Russell, 1973), hlm. 124.

${ }^{31}$ Vicki C. Jackson dan Mark Tushnet membagi dua bentuk atau model lembaga yang melaksanakan constitutional judicial review (pengujian konstitusionalitas oleh lembaga peradilan), yaitu: pertama, the decentralized model atau disebut juga model Amerika atau dalam istilah yang lebih rumit disebut yaitu "diffuse model involving incidental review". Menurut Jackson dan Tushnet, pada model ini, kekuasaan untuk melakukan judicial review dijalankan oleh beberapa lembaga peradilan. Review dalam common law dapat dilakukan oleh banyak lembaga peradilan seperti peradilan federal maupun peradilan negara bagian di Amerika. Kedua, the centralized model yang biasa disebut juga dengan model Austria atau model Eropa. Ciri utama model ini adalah terdapatnya lembaga khusus dalam melakukan kewenangan judicial review. Khusus di sini bermakna tidak terdapat lembaga lain atau lembaga peradilan lain yang melakukan kewenangan judicial review. Feri Amsari, "Masa depan MK: Kesesuaian Teori dan Implementasi", (Jakarta: Jurnal Kosntitusi Mahkamah Konstitusi RI, Vol.5 No. 1, Juni 2008), hlm. 16.

${ }^{32}$ Khelda Ayunita dan Abd. Rais Asman, Hukum Tata Negara, (Jakarta: Mitra Wacana Media, 2016), hlm. vii. 
diserahkan kepada satu lembaga tertinggi saja (the centralized). ${ }^{33}$ Negara penganut sistem ini biasanya memiliki kecenderungan untuk bersikap pasti terhadap doktrin supremasi hukum. Karena itu, penganut sistem sentralisasi biasanya menolak untuk memberikan kewenangan ini kepada pengadilan biasa. ${ }^{34}$ Dalam hal ini, di Indonesia, MK mendukung Perda agar diserahkan pengujiannya hanya ke MA.

\section{Kendala Judicial Review di Mahkamah Agung}

Prosedur hak uji materiil (HUM) MA dibuat dalam bentuk Peraturan Mahkamah Agung (PERMA). Hal itu didasarkan pada pertimbangan bahwa ketentuan undang-undang yang memberi wewenang HUM bagi MA hanya singkat, tanpa mengatur tentang tata cara atau prosedur pelaksanaan HUM. Oleh karena itu, untuk mengisi kekosongan hukum yang akhirnya merugikan pencari keadilan, ditempuhlah cara melalui pembuatan PERMA yang didasarkan pada wewenang MA. ${ }^{35}$

Menurut Pasal 1 ayat (1) PERMA Nomor 1 Tahun 2011 tentang Hak Uji Materil (PERMA HUM), HUM adalah "hak Mahkamah Agung untuk menilai materi muatan peraturan perundang-undangan di bawah undang-undang terhadap peraturan perundang-undangan yang lebih tinggi". ${ }^{36}$ Sesuai dengan ketentuan

\footnotetext{
${ }^{33}$ Dian Rositawati, "Mekanisme Judicial Review", Makalah disampaikan dalam Seri Bahan Bacaan Kursus HAM untuk Pengacara XI Tahun 2007, (Jakarta, Lembaga Studi dan Advokasi Masyarakat, 2007), hlm. 3.

${ }^{34}$ Ibid. hlm. 1 .

35 Achmad Mulyanto, "Problematika Pengujian Peraturan Perundang-Undangan (Judicial Review) Pada Mahkamah Agung dan Mahkamah Konstitusi", (Surakarta: Jurnal Yustisia Vol.2 No.1, April 2013), hlm. 59.

36 Titik Triwulan Tutik, Konstruksi Hukum Tata Negara Pasca Amandemen UUD 1945, (Jakarta: Kencana Prenada Media Group, 2010), hlm. 214.
} 
Pasal 31 Undang-Undang Nomor 3 Tahun 2000 tentang Mahkamah Agung dan Pasal 1 PERMA HUM, obyek HUM meluputi peraturan perundang-undangan, yakni kaidah hukum tertulis yang mengikat secara umum di bawah undangundang. Wewenang tersebut dimulai secara konstitusional dalam Pasal 24A ayat (1) UUD NRI 1945. ${ }^{37}$

MA, sejak diberi wewenang untuk melakukan HUM hingga sekarang, telah membentuk lima kali perubahan PERMA tentang tata cara HUM, yaitu melalui PERMA Nomor 1 tahun 1993 tentang Hak Uji Mteril, PERMA Nomor 1 Tahun 1999 tentang Hak Uji Mteril, PERMA Nomor 2 Tahun 2002 tentang Hak Uji Mteril, PERMA Nomor 1 Tahun 2004 tentang Hak Uji Mteril, dan terakhir diubah melalui PERMA Nomor 1 Tahun 2011 tentang tentang Hak Uji Mteril. Terdapat perubahan aturan dalam PERMA tentang HUM di atas, yaitu mengenai tenggang waktu dalam pengajuan HUM, yang semula dibatasi 180 hari berdasarkan PERMA Nomor 1 Tahun 2004 menjadi dihapuskan. Namun, PERMA terbaru tetap hanya memberikan HUM kepada MA untuk melaksanakan judicial review. Hal ini berarti bahwa MA tidak akan memeriksa atau menguji aspek formil penyusunan dan pembentukan peraturan perundang-undangan di bawah undangundang, termasuk Perda. 38

Secara garis besar, PERMA HUM mengatur hal-hal sebagai berikut: ${ }^{39}$ pertama, tidak ada lagi pengaturan tentang tenggang waktu selama 180 hari sejak peraturan perundang-undangan yang diajukan keberatan ditetapkan. Alasannya, penentuan tenggang waktu tersebut dianggap tidak tepat diterapkan untuk sesuatu

37 Inna Junaenah, "Tafsir Konstitusional Pengujian Peraturan di Bawah UndangUndang”, dalam Jurnal Konstitusi Vol. 13, No. 3, September 2016), hlm. 13.

38 Achmad Mulyanto, Op. Cit, hlm. 60.

${ }^{39}$ Mahkamah Agung, Perma No. 1 Tahun 2011 tentang Hak Uji Materil. 
aturan yang bersifat umum (regelend). Dengan demikian, kapanpun suatu perundang-undangan dapat diajukan permohonan keberatan.

Kedua, permohonan judicial review ke MA diatur dengan menggunakan terminologi Permohonan Keberatan. Dalam PERMA HUM, Permohonan Keberatan adalah suatu permohonan yang berisi keberatan terhadap berlakunya suatu peraturan perundang-undangan yang diduga bertentangan dengan suatu peraturan perundang-undangan yang lebih tinggi yang diajukan ke MA untuk mendapatkan putusan

Ketiga, Permohonan Keberatan diajukan secara langsung ke MA atau melalui Pengadilan Negeri yang membawahi wilayah hukum tempat kedudukan Pemohon. Keempat, Pemohon membayar biaya permohonan pada saat mendaftarkan permohonan keberatan yang besarannya akan diatur tersendiri. Kelima, penetapan Majelis Hakim Agung yang menangani permohonan keberatan dilakukan oleh Ketua Muda Bidang Tata Usaha Negara atas nama Ketua MA.

Keenam, Majelis Hakim Agung memeriksa dan memutus Permohonan Keberatan dengan menerapkan ketentuan hukum yang berlaku dalam waktu yang sesingkat-singkatnya, sesuai dengan asas peradilan yang sederhana, cepat, dan biaya ringan. Ketujuh, putusan tidak dapat diajukan Peninjauan Kembali. Kedelapan, terkait dengan pelaksanaan putusan, jika dalam jangka waktu 90 hari sejak putusan diucapkan, pejabat pembuat peraturan perundang-undangan tidak melaksanakan kewajiban untuk mematuhi putusan, maka peraturan perundangundangan dimaksud tidak lagi mempunyai kekuatan hukum mengikat

Terdapat beberapa catatan untuk diperhatikan terhadap PERMA HUM, karena hukum acara hak uji materiil di MA dalam praktik dianggap belum dapat 
memenuhi harapan pencari keadilan. Kritik yang paling sering, terutama, karena PERMA HUM belum sepenuhnya mengakomodir asas-asas hukum acara pengujian peraturan perundang-undangan. ${ }^{40}$ Pertama, MA dalam pengujian peraturan perundang-undangan di bawah undang-undang tidak menggelar sidang yang terbuka untuk umum. Proses peradilan di MA dalam hal ini lebih bersifat tertutup dan sepihak. Usai berkas permohonan masuk, MA menutup rapat-rapat proses peradilan ini. Para pihak tidak bisa mengetahui sampai mana berkasnya diperiksa dan tidak terdapat satupun ketentuan dalam PERMA HUM yang menyatakan keharusan untuk menggelar sidang secara terbuka. ${ }^{41}$ Padahal, pengujian Perda seharusnya dapat dilakukan secara terbuka.

Permohonan yang ditangani oleh majelis hakim merupakan pengujian peraturan yang bersifat umum atau mengikat masyarakat secara luas dalam suatu wilayah tertentu. Proses pengujian tersebut seharusnya juga dapat menggali kondisi di wilayah hukum Perda yang sedang diuji oleh MA guna dijadikan bahan pertimbangan dalam memutus permohonan. Hal ini dapat ditempuh melalui permintaan keterangan secara langsung pemohon dan termohon yaitu Pemerintah Daerah. Permintaan keterangan juga dapat dilakukan kepada ahli atau elemen masyarakat yang diajukan oleh para pihak. Tentunya, Hakim Agung yang memeriksa permohonan dan berdomisili di Jakarta dihadapkan pada keterbatasan kondisi dan perkembangan suatu daerah.

40 i) Ius Curia Novit (Hakim tidak boleh menolak perkara dengan dalih tidak ada hukumnya); ii) Persidangan Terbuka untuk Umum; iii) Independen dan Imparsial; iv) Peradilan Cepat, Sederhana, dan Biaya Ringan; v) Audi Et Alteram Partem (Hak didengar secara seimbang); vi) Hakim Aktif dalam Persidangan; vii) Presumtio Iustae Causa (Praduga Keabsahan). Taufiqurrahman Syahuri, "Pengkajian Konstitusi tentang Problematika Pengujian Peraturan Perundang-Undangan”, (Jakarta: Badan Pembinaan Hukum Nasional Kemenkumham RI, 2014), hlm. 58 .

41 Ibid. 
Tertutupnya proses uji materiil di MA dinilai rentan mengakibatkan terjadinya penyimpangan dalam proses pengambilan keputusan. Hal itu disampaikan oleh Dosen Fakultas Hukum Universitas Andalas, Feri Amsari, dalam sebuah diskusi bertajuk "Judicial Review secara Terbuka di MA, Mungkinkah?" yang digelar oleh Ikatan Advokat Indonesia (IKADIN). ${ }^{42}$ Berikut grafik jumlah pembatalan Perda di Mahkamah Agung:

Tabel. Jumlah Perkara Hukum HUM

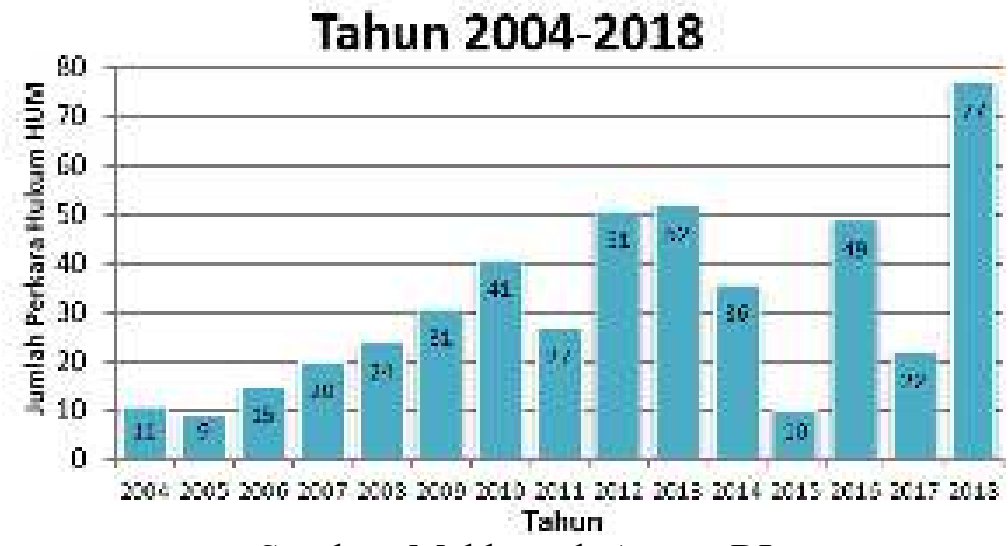

Sumber: Mahkamah Agung RI

Padahal, proses persidangan uji materi akan sangat baik apabila sifatnya terbuka untuk umum. Selain itu, Majelis Hakim Agung juga mengundang pihakpihak yang bersengketa, pihak terkait, termasuk saksi atau ahli seperti dalam persidangan di MK. Dengan demikian, salah paham atau salah implementasi hukum dapat dihindari. Dengan mekanisme persidangan secara tertutup, Majelis Hakim Agung yang sedang menangani perkara tidak mendapatkan input berupa

\footnotetext{
${ }^{42}$ Fachri Fachrudin, “Tertutupnya Proses Uji Materiil di MA Dinilai Rentan Penyimpangan",

http://nasional.kompas.com/read/2017/03/01tertutupnya.proses.uji.materiil.di.ma.dinilai. rentan.penyimpangan, diakses tanggal 1 November 2017.
} 
perspektif atau cara pandang lain terhadap isu hukum perkara yang sedang ditangani. ${ }^{43}$

Kedua, terkait dengan kejelasan dan kepastian, PERMA HUM tidak menentukan batas waktu yang jelas mengenai kapan suatu permohonan akan dan harus disidangkan. Demikian pula, tidak ditentukan kapan permohonan tersebut akan atau harus diputus. Imbas paling sederhana yang mungkin muncul, Pemohon tidak dapat memonitor mengenai bagaimana dan sejauhmana permohonannya diproses di MA. Bahkan, sangat mungkin permohonan tersebut akan sangat lama waktunya sampai diputus, atau sebaliknya, dalam waktu yang tergolong singkat tiba-tiba permohonan keberatan diputus tanpa Pemohon mendapatkan informasi apapun sebelumnya.

Putusan atas perkara judicial review di MA diucapkan dalam sidang yang tidak dihadiri para pihak. Bahkan, sidang dilakukan dalam ruang tertutup di gedung MA dengan pintu yang hanya sedikit saja dibuka. Usai diputus, putusan tidak segera diumumkan ke publik. Banyak putusan judicial review di MA diketahui publik berbulan-bulan setelah diputuskan. Walaupun memiliki laman resmi MA, berkas putusan judicial review acapkali baru diunduh berbulan-bulan setelah diputus. Hal ini berbeda dengan di MK. Putusan diucapkan dalam sidang terbuka untuk umum. Usai diputus, serta merta putusan judicial review itu diserahkan ke para pihak. Tak sampai 10 menit, putusan sudah bisa dilihat di website MK dan bisa diunduh di seluruh penjuru dunia.

Ketiga, terkait dengan isi putusan, putusan MA tidak disertai pendapat hukum hakim secara mendetai seperti dalam putusan No.39 P/HUM/2011. Dalam

\footnotetext{
${ }^{43}$ Taufiqurrahman Syahuri, Op.Cit, h. 63.
} 
putusan tersebut, hanya dituangkan dalam argumen singkat dan padat sehingga maknanya tidak dapat ditangkap secara paripurna. Oleh karenanya, wajar jika masyarakat sering bertanya-tanya apa sesungguhnya maksud dari putusan tersebut. Sedangkan di MK, putusan MK membeberkan seluruh berkas dari awal hingga akhir. Dimuat juga poin-poin pernyataan ahli yang disampaikan dalam persidangan. Putusan MK juga berisi pendapat MK secara tuntas dan detail. Setiap amar selalu diiringi argumen yang tertuang seluruhnya. ${ }^{44}$

Pembenahan perlu dilakukan salah satunya melalui perubahan hukum acara judicial review yang selama ini diatur dalam PERMA HUM. Dengan melihat potensi bertambahnya perkara judicial review pasca putusan MK ini, dibandingkan dengan jumlah hakim agung kamar tata usaha negara yang akan menangani perkara, penambahan jumlah formasi hakim agung kamar tata usaha negara diperlukan. Hal ini dipicu lantaran pada 2016, MA meninggalkan sisa perkara sebanyak 2.357 yang belum selesai diputus meskipun pihak MA mengklaim hal itu sebagai pencapaian tertinggi dari MA dalam menyelesaikan perkara. Sebagaimana dalam laporan kinerja pada 2016, MA menerima beban perkara sebanyak 18.580, yang terdiri dari sisa perkara pada 2015 sebanyak 3.950 . Khusus 2016, tercatat ada 14.630 beban perkara. ${ }^{45}$

Apabila kita melihat pada data Perda yang dibatalkan oleh Pemerintah saja, pada 2016 sebanyak 3143 Perda telah dibatalkan. Walaupun proses judicial review berbeda dengan executive review, di mana judicial review dilakukan atas dasar permohonan dari pihak tertentu, baik kelompok masyarakat atau

\footnotetext{
${ }^{44}$ Ibid hlm. 68 .

${ }^{45}$ Edward Febriyatri Kusuma, "Kurun 2016, MA Vonis 16.223 Perkara" https://news.detik.com, diakses tanggal 1 November 2017.
} 
perorangan. Tetapi, MA tetap harus berbenah dan bersiap mengatur pelaksanaan sidang judicial review. Perlu diingat juga bahwa kewenangan judicial review MA tidak hanya pada Perda, tetapi juga seluruh peraturan perundang-undangan di bawah undang-undang. Pembenahan tersebut salah satunya dapat dilakukan melalui perubahan hukum acara judicial review MA yang selama ini hanya diatur dalam PERMA. Dengan demikian, mengingat banyaknya kualitas Perda Kab/Kota masih jauh dari kondisi ideal, maka kewenangan MA sudah selayaknya harus segera diperbaiki. Terutama pada sisi pedoman hukum acara, daya eksekusi putusan, penguatan dari sisi kualitas putusan, dan penguatan kapasitas hakim itu sendiri.

\section{Penutup}

Adanya dua Putusan Mahkamah Konstitusi yang menghapus wewenang eksekutif review, peran Pemerintah untuk mengawasi Perda pada dasarnya masih dapat dilakukan melalui executive preview. Menteri Dalam Negeri dapat melakukan pengawasan terhadap Rancangan Perda Provinsi dan Gubernur terhadap Rancangan Perda Kabupaten/Kota. Untuk mengawasi Perda melalui mekanisme executive preview, Pemerintah perlu lebih serius dan lebih ketat dalam melakukan supervisi atau mengawal ataupun menyaring rancangan Perda sebelum menjadi Perda. Di samping itu, untuk pembatalan Perda Provinsi maupun Perda Kabupaten/Kota, hanya dapat ditempuh melalui mekanisme judicial review di MA. Terkait proses judicial review di MA, diperlukan perbaikan Peraturan Mahkamah Agung terkait Hak Uji Materil yang selama ini belum memenuhi asasasas hukum acara pengujian peraturan perundang-undangan dalam hal pengujian Perda perlu dilakukan secara terbuka, ditentukan terkait dengan jadwal 
persidangan sampai dengan putusan, dan putusan MA sebaiknya disertai pendapat hukum hakim secara mendetail untuk mendapatkan kepastian hukum bagi seluruh rakyat Indonesia. 


\section{Daftar Pustaka}

\section{Buku}

Asshiddiqie, Jimly, Perihal Undang-Undang, Jakarta: PT RajaGrafindo Persada,2010.

Ayunita, Khelda dan Asman, Abd. Rais, Hukum Tata Negara, Jakarta, Mitra Wacana Media, 2006

Fatmawati, Hak Menguji (Toetsingrecht) yang Dimiliki Hakim dalam Sistem Hukum Indonesia, Jakarta, PT Raja Grafindo Persada, 2005

Farida Indrati, Maria, Ilmu Perundang-Undangan, Yogyakarta, Kanisius, 2016.

Kelsen, Hans, General Theory of Law and State, Transleted by Anders Wedberg, New York, Russell and Russell, 1973

Manan, Bagir, Dasar-dasar Perundang-undangan Indonesia, Jakarta, Indonesia Hill, 1999 , Menyongsong Fajar Otonomi Daerah, Yogyakarta: PSH FH

UII, 2002

Tutik, Titik Triwulan, Konstruksi Hukum Tata Negara Pasca Amandemen UUD 1945, Jakarta, Kencana Prenada Media Group, 2010

Syamsuddin, Aziz, Proses dan Teknik Penyusunan Undang-Undang, Jakarta, Sinar Grafika, 2013

\section{Jurnal}

Anjarsari, Lulu, "Pembatalan Perda Kabupaten/Kota (Menjadi) Kewenangan MA”, Jurnal Konstitusi, No. 123, Mei 2017

Ghoffar, Abdul, "Kuasa Membatalkan Undang-Undang”, Jurnal Konstitusi, Nomor 122, April 2017 
Junaenah Inna, "Tafsir Konstitusional Pengujian Peraturan di Bawah UndangUndang”, Jurnal Konstitusi, Vol. 13, Nomor. 3, September 2016

Kurniawati, Yuniar, "Polemik Pengujian Peraturan Daerah (UU No.48 Tahun 2009 tentang Kekuasaan Kehakiman Versus UU No.23 Tahun 2014 tentang Pemerintahan Daerah”, Jurnal Litigasi, Vol. 13, Nomor 4, 2016

Mahfud MD, Moh,“Konstitusi Negara”, Makalah disampaikan dalam Acara Orientasi Anggota DPR RI Fraksi PDI Perjuangan 2009-2014

Marzuki H.M. Laica, "Desentralisasi dalam Sistem Ketatanegaraan", Jurnal Konstitusi, Vol. 4, Nomor 1, Maret, 2017

Mulyanto,Achmad, "Problematika Pengujian Peraturan Perundang-Undangan

(Judicial Review) Pada Mahkamah Agung dan Mahkamah Konstitusi”, Jurnal Yustisia Vol.2 Nomor 1, April 2013

Pusat Studi Hukum dan Kebijakan Indonesia, "Laporan Kajian tentang Implementasi Pengawasan Perda oleh Pemerintah dan Mahkamah Agung”, Pusat Studi Hukum dan Kebijakan Indonesia, 2011

Sholikin, M. Nur, "Penghapusan Kewenangan Pemerintah Untuk Membatalkan Perda;Momentum Mengefektifkan Pengawasan Preventif dan Pelaksanaan Hak Uji Materil MA”, RechtsVinding Online, Mei 2017

Syahuri Taufiqurrahman, "Pengkajian Konstitusi tentang Problematika Pengujian Peraturan Perundang-Undangan”, Badan Pembinaan Hukum Nasional, 2014

\section{Peraturan Perundang-Undangan}

Indonesia, Undang-Undang Dasar Negara Republik Indonesia Tahun 1945. Indonesia, Undang-Undang Nomor 3 Tahun 2009 tentang Mahkamah Agung. 
Indonesia, Undang-Undang Nomor 12 Tahun 2011 tentang Pembentukan Peraturan Perundang-Undangan.

Indonesia, Undang-Undang Nomor 23 Tahun 2014 tentang Pemerintah Daerah:

Mahkamah Agung, Peraturan Mahkmah Agung Nomor 1 Tahun 2011 tentang Hak Uji Materil.

Mahkamah Konstitusi, Putusan Nomor 137/PUU-XIII/2015.

Mahkamah Konstitusi, Putusan Nomor 56/PUU-XIV/2016

\section{Website}

Fachrudin, Fachri, "Tertutupnya Proses Uji Materiil di MA Dinilai Rentan Penyimpangan", http://nasional.kompas.com/read/2017/03/01 tertutupnya.proses.uji.materiil.d i.ma.dinilai. rentan.penyimpangan, diakses pada 12 Maret 2017.

Kusuma, Edward Febriyatri, "Presiden-DPR Diminta Ubah Aturan Sidang JR di MA Jadi Terbuka”, https://news.detik.com/berita/3435404/presiden-dprdiminta-ubah-aturan-sidang-jr-di-ma-jadi-terbuka, diakses pada 1 Maret 2017.

Kusuma, Edward Febriyatri, "Kurun 2016, MA Vonis 16.223 Perkara" https://news.detik.com, diakses pada 09 Februari 2017. 
48 ADIL: Jurnal Hukum Vol. 10 No.2 